\title{
PRODUCTION DYNAMICS OF Spartina alterniflora SALT MARSHES IN THE ESTUARY OF PATOS LAGOON (RS, BRAZIL): A SIMULATION MODEL APPROACH
}

\author{
CUNHA, S.R. ${ }^{1}$; ASMUS, M. $^{2} \&$ COSTA, C.S.B. ${ }^{2}$ \\ 'Lab. Ecologia da Vegetação Costeira, CTTMar/UNIVALI. Rua Uruguai, 458 - Itajaí, SC. CEP:88302- \\ 202. e-mail: simone.cunha@univali.br; \\ 2Departamento de Oceanografia, FURG, Cx.Postal 474. Rio Grande, RS. CEP: 96201-900.
}

\begin{abstract}
Cunha, S.R.; Asmus, M. \& Costa, C.S.B. 2005. Production dynamics of Spartina alterniflora salt marshes in the estuary of Patos Lagoon (RS, Brazil): A Simulation model approach. Braz. J. Aquat. Sci. Technol. 9(2):7585. ISSN 1808-7035. We aimed to study the dynamics of ecological processes concerning primary production of an irregularly flooded short Spartina alterniflora (height $49.98 \pm 20.65 \mathrm{~cm}$ ) salt marsh in the estuarine zone of Patos Lagoon

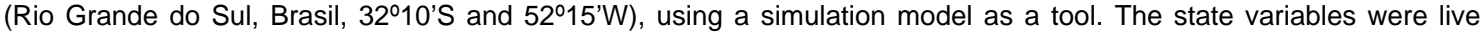
aboveground biomass of Spartina, standing dead biomass, detritus from Spartina at the sediment's surface, live and dead belowground biomass. Simulated processes were primary production, mortality, allocation, reallocation, respiration and decomposition. Forcing functions were light radiation, temperature, salinity, water level, precipitation, air humidity and percentage of nitrogen in the aerial live vegetal tissues. The model was simulated for September/1992 to May/1994. In order to check the model, Spartina were monthly collected for this period, sorted, dried at $80^{\circ} \mathrm{C}$ and weighted. Abiotic data were daily measured at the study site. Shoots (live and dead) showed a strong seasonal pattern, ranging from $798.85 \pm 172.66 \mathrm{~g} \mathrm{~m}^{-2}$ to $304.12 \pm 55.53 \mathrm{~g} \mathrm{~m}^{-2}$. Roots varied from $3977.07 \pm 687.40 \mathrm{~g} \mathrm{~m}^{-2}$ to $1477.47 \pm 551.49 \mathrm{~g} \mathrm{~m}^{-2}$, but without seasonal pattern. The model showed a good agreement with observed data, especially for live above and belowground biomass. The sensitivity analysis indicated temperature as the main system controller. Changes in temperature values modified not only biomasses values of all state variables, but also changed the seasonal patterns of standing dead and dead belowground biomasses. Primary production and translocation processes were very sensitive to environmental changes. The use of a function representing losses of detritus from the marsh surface avoided a detritus accumulation effect in the simulation, which represented an amount of $573 \mathrm{~g} \mathrm{~m}^{-2}$ of organic matter to be consumed by marsh organisms or exported to the estuary by tide or runoff. This value was similar to annual aerial productivity estimated to these marshes. The estimated aerial productivity of the model $\left(673.69 \mathrm{~g} \mathrm{~m}^{-2}\right.$ year-1 $\left.^{-1}\right)$ was very similar to that estimated by Smalley method $\left(668.79 \mathrm{~g} \mathrm{~m}^{-2}\right.$ year-1), as well as the turnover rate, with values of 2.93 and $3.08 \mathrm{year}^{-1}$, respectively. This model allowed us to evaluate the influence of abiotic factors on primary productivity of Spartina marshes in Patos Lagoon, and indicates temperature as the most important forcing function to productive process. It also allowed us to estimate the amount of litter which left the marsh, been exported or consumed during this study, with the rain playing a major role in this process.
\end{abstract}

Keywords: Spartina alterniflora, salt marshes, primary production, modeling

\section{INTRODUCTION}

Among estuarine habitats, salt marshes have been considered as an important producer and potential exporter of organic matter to estuarine and coastal waters (Mitsch \& Gosselink, 1986; Day et al., 1989; Adam, 1990). Salt marshes are physically complex environments, including terrestrial and aquatic components and have properties specific of these areas (Mitsch et al., 1988; Adam, 1990). The importance of hydrological, geochemical and microbiological factors have been emphasized by several authors as controllers of the nutrients and organic matter fluxes between salt marshes and adjacent waters (Newell et al., 1985; Jordan et al., 1986; Wolaver et al., 1986; Mann, 1988). Many of these factors are, at least, indirectly related with the growth dynamics of dominant plants of a salt marsh.

The understanding of seasonal and annual vegetation dynamics are quite important to evaluate the role that salt marshes play on the estuarine and coastal environments. The modeling approach is a very useful tool to describe and quantify the dynamic processes and interactions in the salt marshes, as has been shown by many authors (Summers \& McKellar, 1978; Wiegert, 1980; Wiegert et al., 1981; Childers \& McKellar, 1987; Asmus, 1990; Cunha, 1994).

This work aims to study the productive processes of above and belowground components of a Spartina alterniflora salt marsh at Patos Lagoon estuary, using a simulation model that integrates its dominant processes and environmental factors. 


\section{Study site and measurements}

The Patos Lagoon estuary is located at the Southern Brazilian Coastal Plain (32 ${ }^{\circ} 0^{\prime}$ S e $52^{\circ}{ }^{\prime} 5^{\prime}$ $\mathrm{W})$. The climate is subtropical temperate. The daily solar radiation ranges from 3800 to $2132 \mathrm{Kcal} \mathrm{m}^{-2}$. The daily mean air temperature ranges from 23 to $13^{\circ} \mathrm{C}$. The annual rainfall is around $1200 \mathrm{~mm}$, with a dry period in the summer. The astronomic tide is not important and the water level variation is mainly controlled by wind and rainfall in the hydrographic basin.

Salinity, water temperature, and water level, used as forcing functions in the model were daily measured in the study area. Daily data of rainfall and relative air humidity were obtained from the Meteorological Station of the University of Rio Grande. Daily data on solar incident radiation in the region were obtained from the Agronomic Institute of Rio Grande do Sul.

Spartina alterniflora biomass was monthly sampled in a monospecific meadow located on Pólvora Island (Figure 1), from October 1992 to May 1994, 5 m from the edge of the bed, where the flooding frequency was $18,5 \%$ of the days in the sampling period. The sampling location selection took into account the homogeneity of cover, density and height of short (49.98 $\pm 20.65 \mathrm{~cm}$ ) Spartina, as well as the size of the bed, big enough to ensure adequate sampling with minimum damage to the environment. The aboveground biomass was determined by clipping vegetation in five samplers of $0,25 \mathrm{~m}^{-2}$, as well as surface litter. Belowground biomass was sampled using 10 cores of $10 \mathrm{~cm}$ diameter, buried $45 \mathrm{~cm}$ deep into the ground. In laboratory, samples were cleaned and sorted in live aboveground biomass, standing dead biomass, surface litter, and live and dead belowground biomass. Sorting was made based on color and texture of leaves, roots and rhizomes. The sorted samples were dried to constant weight at 80 to $90^{\circ} \mathrm{C}$.

\section{Model description}

Conceptual and mathematical models were built to represent and simulate the biomass of Spartina alterniflora in the Patos Lagoon estuary, based on the methodology proposed by Odum (1983) and Jørgensen (1994). The conceptual model was built based on field observations and scientific literature about Spartina, using the energy language proposed by Odum (1983).
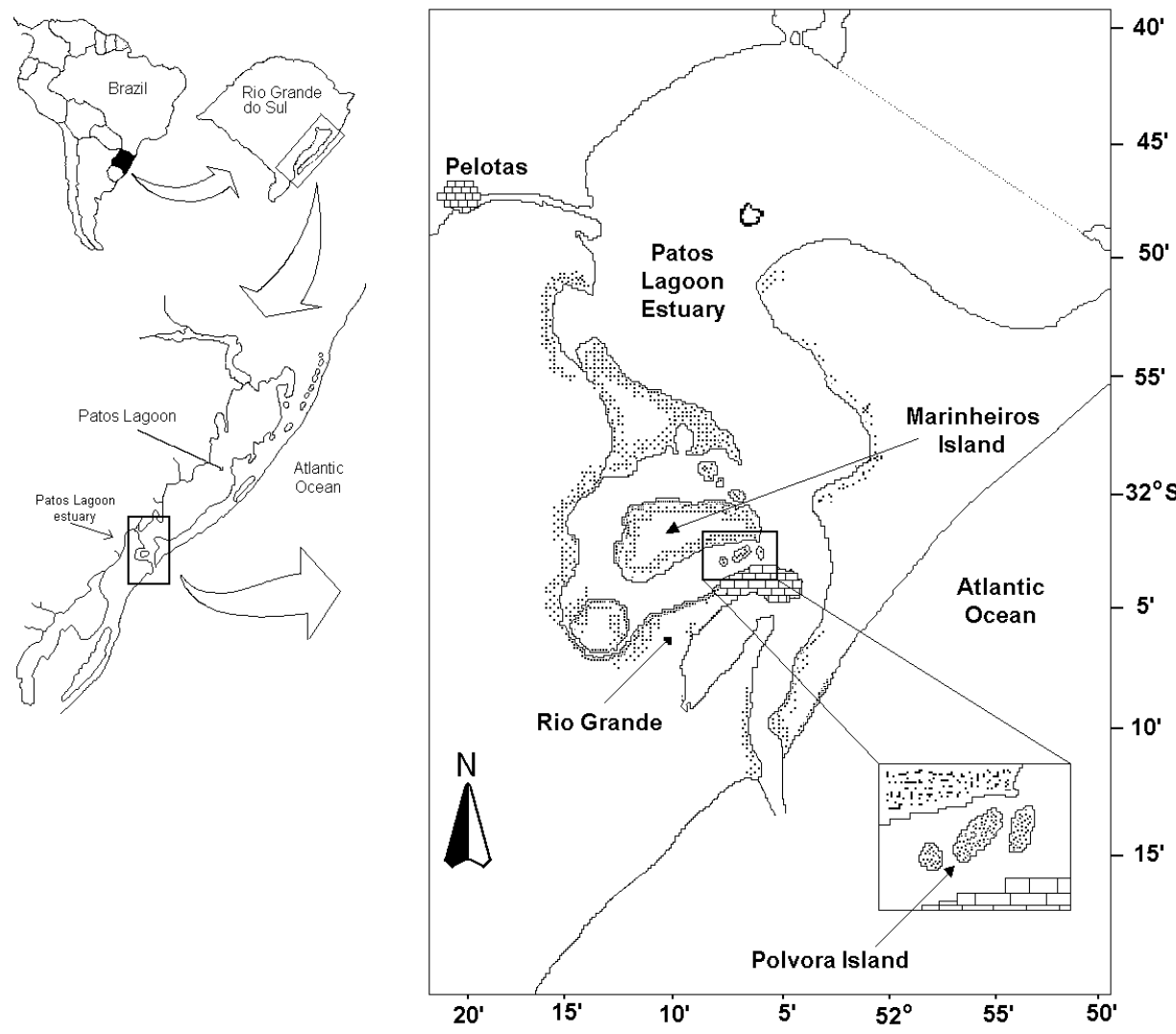

Figure 1 - Patos Lagoon estuary, and the sampling location, Pólvora Island. The dashed area are the salt marshes. 
The diagrammatic model in the Figure 2 represents the structure of the simulation model. The state variables were simulated by differential equations, as presented in the Table 1, and were expressed as $g$ $\mathrm{m}^{-2}$. The flows of matter, simulated by linear and non linear equations and expressed as $\mathrm{g} \mathrm{m}^{-2}$ day ${ }^{-1}$ (dry weight), and also the forcing functions, are presented in Table 2. The parameters and coefficients used are presented in Table 3. The model used a 1-day time step ( $\mathrm{dt}=1$ day), and the eulerian integration method. The mathematical formulation was based on literature about physiological responses of Spartina to environmental factors, and previous salt marsh model of Asmus (1990). These formulations were described in detail by Cunha (1994).

The forcing functions used in the model are: solar radiation (SUN, Kcal m${ }^{-2}$ day $^{-1}$ ), variation of sun angle throughout the year (ANGSUN, radians), day length (DL, hours day $\left.^{-1}\right)$, water temperature (TEMP, $\left.{ }^{\circ} \mathrm{C}\right)$, salinity (SAL), salinity limitation factor (LSAL), nitrogen concentration in the Spartina alterniflora leaves (N, \% of dry weight), nitrogen limitation factor (LNIT), water level in the salt marsh (NA, cm), rain in Rio Grande (RAIN, mm) and relative air humidity (HUM, \%). The state variables of the model are: live aboveground biomass (LA), standing dead biomass (SD), litter (surface detritus, LIT), live belowground biomass (LB), dead belowground biomass (BD). The ecological pro- cesses simulated are: gross primary production (GP) of Spartina, respiration of live aboveground biomass (LARESP), respiration of live belowground biomass (LBRESP), transference of photosynthate from above to belowground biomass (allocation, ALOC), transference of stocked matter from below to aboveground biomass (reallocation, REALOC), mortality of live aboveground (LAMORT) and mortality of live belowground biomass (LBMORT), litter production (fall of standing dead Spartina to the sediment surface, LITPROD), decomposition of standing dead biomass (DECSD), decomposition of litter (LITDEC), decomposition of dead belowground biomass (BDDEC) de Spartina.

The model was validated comparing simulations and observed data for a 21-month period (September 1992 to May 1994). The initial values of the state variables were calculated to September 1 in 1992, by interpolation of observed biomass from August 16 to September 15 in 1993. The validation was made by direct graphic comparisons between model output and observed values of biomass, as well as by "Student's t" test for paired samples. Bilateral tests were made to check the null hypothesis. Unilateral tests were made to compare model output with mean observed biomass plus one standard deviation, and with mean observed iomass minus one standard deviation.

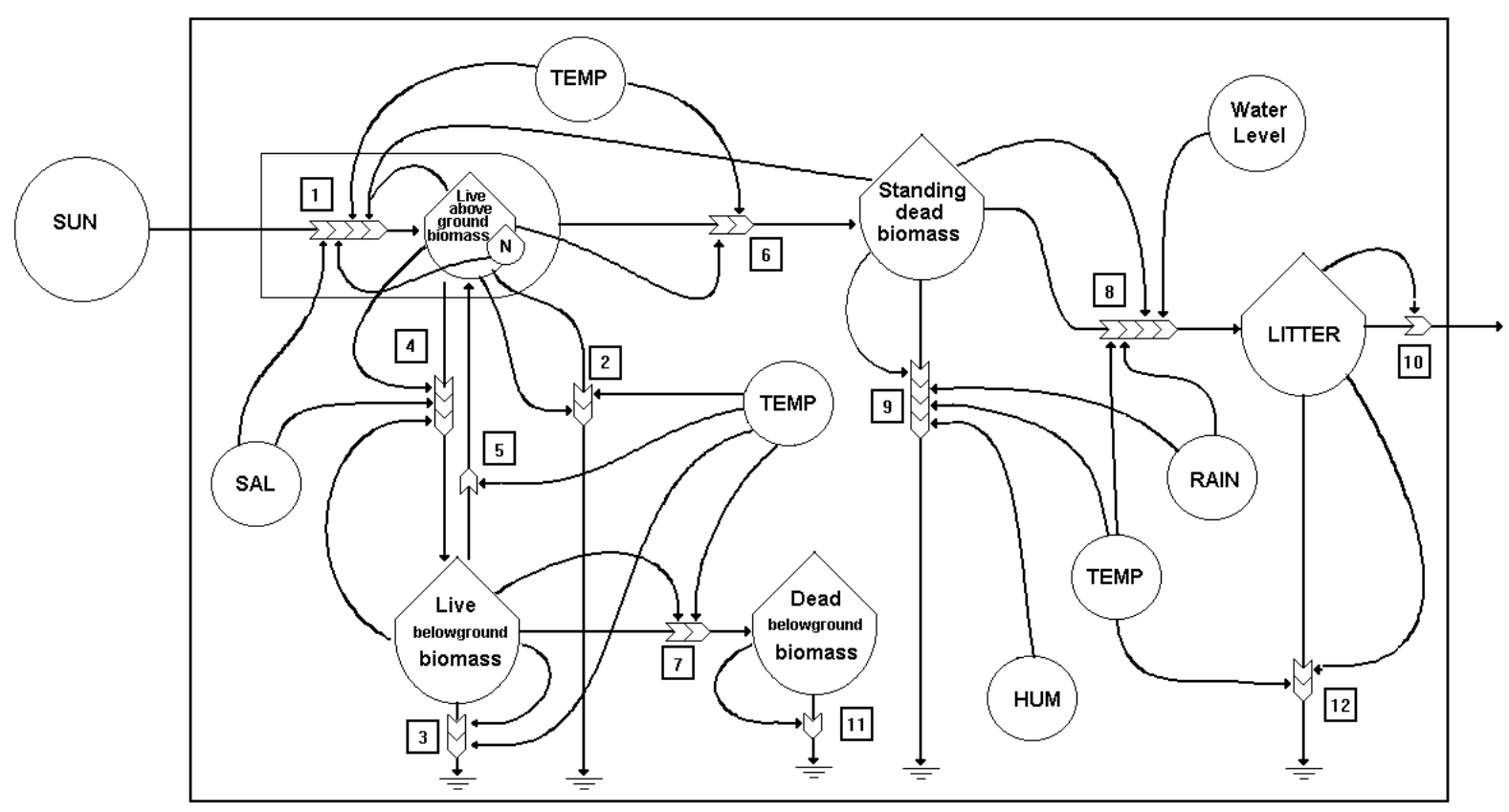

Figure 2 - Conceptual model of Spartina alterniflora salt marshes, that represents the energy source: solar radiation (SUN); the controllers: temperature (TEMP), salinity (SAL), nitrogen concentration in the leaves (N), rain (RAIN), relative air humidity (HUM) and water level; the state variables: live above and belowground biomass, standing dead biomass, dead belowground biomass and litter; the processes: gross primary production (1), aboveground respiration (2), belowground respiration, (3), allocation (4), reallocation (5), aboveground mortality (6), belowground mortality (7), litter production (8), standing dead biomass decomposition (9), litter decomposition (10), dead belowground decomposition (11), litter disappearance (12). The symbols are used as proposed by Odum (1983). 
Cunha et al:: Production dynamics of Spartina alterniflora.

Table 1 - State variables of the model, their differential equations and initial values $\left(\mathrm{g} \mathrm{m}^{-2}\right)$.

\begin{tabular}{|c|c|c|}
\hline State Variables $\left(\mathrm{g} \mathrm{dw} \mathrm{m}^{-2} \mathrm{dia}^{-1}\right)$ & Differential equations & initial values \\
\hline live aboveground biomass & $\mathrm{LA}=\mathrm{LA}+\mathrm{dt} \cdot(\mathrm{GP}-\mathrm{LARESP}-\mathrm{ALOC}+\mathrm{REALOC}-\mathrm{LAMORT})$ & 95.9 \\
\hline standing dead biomass & $\mathrm{SD}=\mathrm{SD}+\mathrm{dt} \cdot($ LAMORT $-\mathrm{DECSD}-\mathrm{LITPROD})$ & 266.8 \\
\hline litter & LIT = LIT + dt · (LITPROD - LITDEC- LITDES) & 26.2 \\
\hline live belowground biomass & $\mathrm{LB}=\mathrm{LB}+\mathrm{dt} \cdot(\mathrm{ALOC}-\mathrm{REALOC}-\mathrm{LBRESP}-\mathrm{LBMORT})$ & 1637.5 \\
\hline dead belowground biomass & $\mathrm{BD}=\mathrm{BD}+\mathrm{dt} \cdot(\mathrm{LBMORT}-\mathrm{BDDEC})$ & 660 \\
\hline
\end{tabular}

Table 2 - Processes, forcing functions and limiting factor of the model, their equations and references.

\begin{tabular}{|c|c|c|}
\hline Ecological processes $\left(\mathrm{g} \mathrm{g}^{-1} \mathrm{~m}^{-2} \mathrm{dia}^{-1}\right)$ & Equations & References \\
\hline Gross primary production & $\mathrm{GP}=\mathrm{PMAX} \cdot \mathrm{LLIG} \cdot \mathrm{LNIT} \cdot \mathrm{LSAL} \cdot \mathrm{TEMP} \cdot \mathrm{DL} \cdot \mathrm{LA}$ & $\begin{array}{l}\text { Morris, 1982; Morris et al., } \\
\text { 1984; Asmus, } 1990\end{array}$ \\
\hline Light limitation factor & $\begin{aligned} \text { LLIG }= & \frac{\sin (\mathrm{ANGSUN})}{-\mathrm{KE} \cdot(\mathrm{LA}+\mathrm{SD})} \cdot\left\{\ln \left[\frac{\mathrm{SUN}}{\mathrm{DL}} \cdot \exp \left(\frac{-\mathrm{KE} \cdot(\mathrm{LA}+\mathrm{SD})}{\sin (\mathrm{ANGSUN})}\right)+\mathrm{KI}\right]\right\} \\
& +\left\{+\ln \left(\frac{\mathrm{SUN}}{\mathrm{DL}}+\mathrm{KI}\right)\right\}\end{aligned}$ & Morris, 1982; 1989 \\
\hline Nitrogen limitation factor & $\mathrm{LNIT}=\frac{\mathrm{N}}{(\mathrm{N}+\mathrm{KNA})}$ & $\begin{array}{l}\text { Morris, 1982; Bradley \& } \\
\text { Morris, } 1992\end{array}$ \\
\hline Salinity limitation factor & $\mathrm{LSAL}=\mathrm{INTERSUN}+\mathrm{DECLSUN} \cdot \mathrm{SAL}$ & Longstreth \& Strain, 1977 \\
\hline Respiration of live aboveground biomass & LARESP $=\mathrm{KRESP} \cdot 24 \cdot \mathrm{TEMP} \cdot \mathrm{LA}$ & Morris, 1982 \\
\hline Respiration of live belowground biomass & LBRESP $=24 \cdot \mathrm{KRESP} \cdot 0,3 \cdot \mathrm{LB}$ & $\begin{array}{l}\text { Morris, 1982; Gleason \& } \\
\text { Dunn, } 1982\end{array}$ \\
\hline $\begin{array}{l}\text { Allocation of photosynthate from live } \\
\text { aboveground to live belowground } \\
\text { biomass }\end{array}$ & $\mathrm{ALOC}=\frac{\mathrm{LA}+\mathrm{LB}}{\mathrm{LB}} \cdot \mathrm{SALAL} \cdot(\mathrm{GP}-\mathrm{LARESP})$ & $\begin{array}{l}\text { Lytle \& Hull, 1980a,c; } \\
\text { Asmus, 1990; numerically } \\
\text { adjusted }\end{array}$ \\
\hline $\begin{array}{l}\text { Reallocation of matter from belowground } \\
\text { to aboveground biomass }\end{array}$ & $\begin{array}{l}\text { REALOC }=\left(-1,6594 \cdot 10^{-2}+2,6323 \cdot 10^{-3} \cdot \text { TEMP }-7,2332 \cdot 10^{-5}\right. \\
\left.\cdot \text { TEMP }^{2}\right) \cdot 0,25 \cdot \text { LB }\end{array}$ & $\begin{array}{l}\text { Lytle \& Hull, 1980b; } \\
\text { numerically adjusted }\end{array}$ \\
\hline Mortality of live aboveground biomass & LAMORT $=$ LA $\cdot$ KLAMORT & $\begin{array}{l}\text { This study, calculated by } \\
\text { Smalley method }\end{array}$ \\
\hline Mortality of live belowground biomass & $\mathrm{LBMORT}=\mathrm{LB} \cdot \mathrm{KLBMORT}$ & $\begin{array}{l}\text { This study, calculated by } \\
\text { Smalley method and } \\
\text { numerically adjusted }\end{array}$ \\
\hline \multirow[t]{4}{*}{$\begin{array}{l}\text { Litter production (fall of standing dead } \\
\text { Spartina to the sediment surface) }\end{array}$} & LITPROD $=$ SD. TEMP $\cdot$ WL. AWL $\cdot$ WVAR $\cdot 0.07 \cdot\left(1+\frac{\mathrm{R}}{-}\right.$ & $\begin{array}{l}\text { This study, numericaly } \\
\text { adjusted }\end{array}$ \\
\hline & $\mathrm{WL}=$ water level; $\mathrm{AWL}=$ average $\mathrm{WL}$ & \\
\hline & WVAR $=$ if $W V A R<0$ then [WVAR $\cdot(-1)]$ else & \\
\hline & (WVAR) & \\
\hline \multirow[t]{2}{*}{ Decomposition of standing dead biomass } & $\mathrm{DSD}=\mathrm{KLSD} \cdot \mathrm{FC} \cdot \mathrm{SD}$ & Newell et al., 1985, this study \\
\hline & DECSD $=$ if RAIN $<10$ then $[\mathrm{KHUM} \cdot \mathrm{DSD}]$, else DSD & \\
\hline Litter decomposition & $\mathrm{LITDEC}=\mathrm{KD} \cdot \mathrm{LIT} \cdot(1-\mathrm{REFR}) 1$ & Asmus, 1990 \\
\hline $\begin{array}{l}\text { Decomposition of dead belowground } \\
\text { biomass }\end{array}$ & $\mathrm{BDDEC}=\mathrm{BD} \cdot 0,0035$ & Benner et al., 1991; Blum, 1993 \\
\hline Litter disappearance & LITDES $=$ if LIT $>20$, then LIT $\cdot 0,05$ & $\begin{array}{l}\text { This study, numerically } \\
\text { adjusted }\end{array}$ \\
\hline
\end{tabular}

\section{RESULTS AND DISCUSSION}

\section{Live aboveground biomass}

The model output for live aboveground biomass of Spartina alterniflora showed excellent agreement with observed data (Figure 3A). The maximum values of simulated and observed live aboveground biomass occurred in the summer 1993 (March and April). Biomass production estimated by the model in the first studied growth period (01/Sep/92 to 01/May/93) was significantly higher than in the second period (01/Sep/93 to 01/May/ 94), but solar radiation was not significantly different in both periods (Table 4). Salinity was significantly different, but it was very close to the optimal value for Spartina growth. Temperature exhibited significantly lower values 
Braz. J. Aquat. Sci. Technol., 2005, 9(2):75-85.

Table 3 - Parameters and coefficients of the model, their equations and references.

\begin{tabular}{|c|c|c|}
\hline Parameters and coefficients & Equations and values & References \\
\hline $\begin{array}{l}\text { Maximum weight-specific rate of } \\
\text { photosynthesis }\left(\mathrm{g} \mathrm{g}^{-1}{ }^{\circ} \mathrm{C}^{-1} \mathrm{~h}^{-1}\right)\end{array}$ & PMAX $=0,00071$ & Morris, 1982. \\
\hline $\begin{array}{l}\text { Nitrogen concentration in the leaves (\% dry } \\
\text { weight) }\end{array}$ & $\mathrm{N}$ & Panitz, 1986 \\
\hline $\begin{array}{l}\text { Half saturation constant for nitrogen, adjusted } \\
\text { in relation to salinity }(\%)\end{array}$ & $\mathrm{KNA}=\left[0,26247 \cdot 10^{(0,0086443 \cdot \mathrm{SAL})}\right]$ & $\begin{array}{l}\text { Morris, 1982; Bradley \& Morris, } \\
1992 .\end{array}$ \\
\hline $\begin{array}{l}\text { Light extinction coefficient through the } \\
\text { canopy }\left(\mathrm{g} \mathrm{m}^{-2} \mathrm{~cm}^{-1}\right)\end{array}$ & $\mathrm{KE}=3,4 \cdot 10^{-4}$ & Morris, 1982; 1989 \\
\hline $\begin{array}{l}\text { Half saturation constant for photosynthesis } \\
\left(\mathrm{Kcal} \mathrm{m}^{-2} \mathrm{~h}^{-1}\right)\end{array}$ & $\mathrm{KI}=258,12$ & Morris, 1982; 1989 \\
\hline $\begin{array}{l}\text { Intersection among salinity limitation factor } \\
\text { curve and axis of solar radiation }\end{array}$ & INTERSUN $=1,3175-6,3178 \cdot 10^{-5} \cdot \mathrm{SUN}$ & $\begin{array}{l}\text { Longstreth \& Strain, 1977; } \\
\text { Asmus, } 1990 .\end{array}$ \\
\hline $\begin{array}{l}\text { Declivity of salinity limitation factor curve in } \\
\text { relation of solar radiation }\end{array}$ & DECLSUN $=-3,1724 \cdot 10^{-2}+6,3054 \cdot 10^{-6} \cdot \mathrm{SUN}$ & $\begin{array}{l}\text { Longstreth \& Strain, 1977; } \\
\text { Asmus, } 1990\end{array}$ \\
\hline Day length $\left(\mathrm{h} \mathrm{day}^{-1}\right)$ & $\mathrm{DL}=12+2,1 \cdot \cos \left(\frac{2 \cdot \pi}{365} \cdot(\right.$ day -253$\left.)\right)$ & Brock, 1981 \\
\hline Solar angle (degrees) & ANGSUN $=57,4+23,25 \cdot \cos \left(\frac{2 \cdot \pi}{365} \cdot(\right.$ day -253$\left.)\right) \cdot \frac{2 \cdot \pi}{360}$ & Brock, 1981 \\
\hline $\begin{array}{l}\text { Respiration rate of S. alterniflora }\left(\mathrm{g} \mathrm{g}^{-1}{ }^{\circ} \mathrm{C}^{-1} \mathrm{~h}^{-}\right. \\
\left.{ }^{1}\right)\end{array}$ & $\mathrm{KRESP}=0,000023$ & $\begin{array}{l}\text { Lytle \& Hull, } 1980 \text { a,c; } \\
\text { numerically adjusted }\end{array}$ \\
\hline Salinity influence on allocation (unitless) & SALAL $=0,772397+0,2472 \cdot 10^{-2}$ & $\begin{array}{l}\text { Linthurst e Blum, 1981; } \\
\text { numerically adjusted }\end{array}$ \\
\hline $\begin{array}{l}\text { Mortality rate of live aboveground biomass } \\
\left(\mathrm{g} \mathrm{g}^{-1} \mathrm{day}^{-1}\right)\end{array}$ & KLAMORT $=6,4475 \cdot 10^{-2}-4,2124 \cdot 10^{-2} \cdot \log ($ TEMP $)$ & $\begin{array}{l}\text { This study, calculated by } \\
\text { Smalley method }\end{array}$ \\
\hline $\begin{array}{l}\text { Mortality rate of live belowground biomass } \\
\left(\mathrm{g} \mathrm{g}^{-1} \text { day }^{-1}\right)\end{array}$ & KLBMORT $=7,7949 \cdot 10^{-3}-5,072 \cdot 10^{-3} \cdot \log ($ TEMP $)$ & $\begin{array}{l}\text { This study, calculated by } \\
\text { Smalley method and } \\
\text { numerically adjusted }\end{array}$ \\
\hline $\begin{array}{l}\text { Decomposition rate of standing dead biomass } \\
\left(\mathrm{g} \mathrm{g}^{-1} \text { day }^{-1}\right)\end{array}$ & $\mathrm{KLSD}=\mathrm{e}^{(0,075 \cdot \mathrm{TEMP}+2,68)}$ & Newell et al., 1985 \\
\hline $\begin{array}{l}\text { Conversion factor from } \mu \mathrm{g} \mathrm{C} \mathrm{g}^{-1} \mathrm{~h}^{-1} \text { to } \mathrm{g} \mathrm{dw} \\
\mathrm{g}^{-1} \text { day }^{-1}\end{array}$ & $\mathrm{FC}=\left(2,381 \cdot 10^{-6} \cdot 24\right)$ & This study \\
\hline $\begin{array}{l}\text { Relation among relative air humidity and } \\
\text { standing dead biomass decomposition } \\
\text { (unitless) }\end{array}$ & $\left.\mathrm{KHUM}=1,0288 \mathrm{E}-4 \cdot 10^{(3,8070 \mathrm{E}-2} \cdot \mathrm{HUM}\right)$ & Newell et al., 1985 \\
\hline Decomposition rate of litter $\left(\mathrm{g} \mathrm{g}^{-1}\right.$ day $\left.^{-1}\right)$ & $\mathrm{KD}=-7,2093 \cdot 14^{-4}+3,362 \cdot 10^{-4} \cdot \mathrm{TEMP}$ & Asmus, 1990 \\
\hline Refractory portion of Spartina alterniflora & REFR $=0.173$ & Asmus, 1990 \\
\hline
\end{tabular}

in the second period. These results indicate that Spartina biomass was more affected by temperature, than by solar radiation or salinity.

The strong control of Spartina by temperature is certainly a consequence of its metabolism. Spartina production shows a linear relationship with temperature up to a high value of $35^{\circ} \mathrm{C}$ (Giurgevich \& Dunn, 1979; Drake, 1989; Nobel, 1991), and its response to solar radiation shows a hyperbolic behavior, in spite of the high saturation level of this plant (Drake, 1989; Nobel, 1991).

The magnitude of live aboveground biomass depends on production and mortality, but also depends on allocation and reallocation of material between aboveground and belowground biomass. Nobel (1991) suggested that $\mathrm{C}_{4}$ plants could rapidly transfer the photosynthate from above to belowground biomass, due to their intense leaf vascularization. The model suggests that the observed balance between Spartina above and belowground biomass requires high rates of photosynthate allocation, which can represent from 80 to $92 \%$ of net primary production. When we simulate allocation rates approximately $80 \%$ of the standard rates, the magnitude of live aboveground biomass greatly increases, due to accumulation of aerial biomass (Figure 3B). However, if the allocation rates are increased, the live aboveground biomass cannot sustain its magnitude. When the allocation rates are about $120 \%$ of the standard rates, the live aboveground biomass tends to disappear, collapsing the system.

During the early growth season, the vegetative growth of Spartina drew upon energy stored in rhizomes from the previous year, through reallocation process (Lytle \& Hull, 1980b; Hopkinson \& Schubauer, 1984). The model outputs suggest that this process is essential to control the biomass magnitude, since the photosynthesis realized only by the biomass present in the end of the previous winter is not enough to produce 

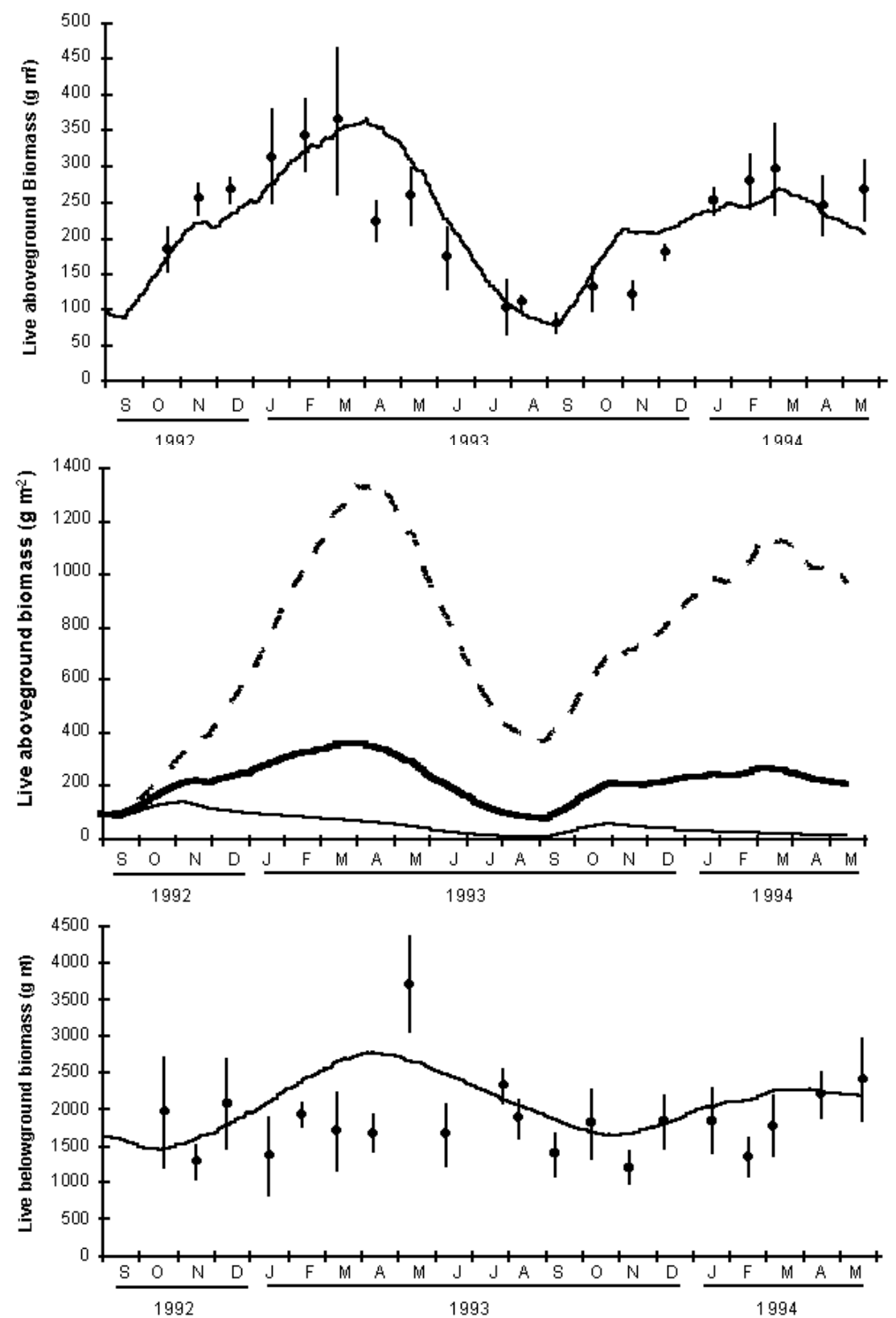

C

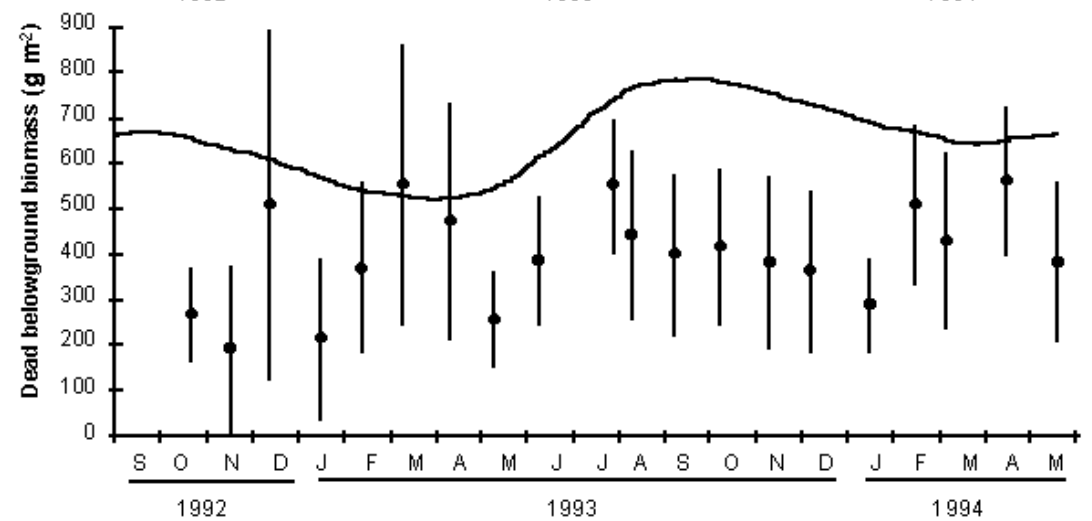

Figure 3 - Continuous lines are simulation output, points are mean observed values and vertical lines are one standard deviation. (A) Observed and simulated live aboveground biomass; (B) Simulated live aboveground biomass in: (thick line) standard simulation, (dashed line) simulation with allocation rate as $80 \%$ of standard simulation, (thin line) simulation with allocation rate as $80 \%$ of standard simulation; (C) Observed and simulated live belowground biomass; (D) Observed and simulated dead belowground biomass. 
Table 4 - Comparison of net primary production using different calculations, and comparison of mean value of the environmental conditions for both growth periods of Spartina alterniflora studied in this work.

\begin{tabular}{|c|c|c|c|c|}
\hline & $\begin{array}{l}\text { Period from } \\
\text { 01/Sep/92 to 31/May/93 }\end{array}$ & $\begin{array}{l}\text { Period from } \\
\text { 01/Sep/93 to 31/May/94 }\end{array}$ & $\mathrm{n}$ & $\begin{array}{l}* * \alpha \\
= \\
0,05\end{array}$ \\
\hline Aboveground production (Smalley method) & $385,46 \mathrm{~g} \mathrm{~m}^{-2}$ & $348,05 \mathrm{~g} \mathrm{~m}^{-2}$ & 6 & ns \\
\hline Aboveground production (reallocation included) $\mathbf{0}$ & $467,38 \mathrm{~g} \mathrm{~m}^{-2}$ & $430,70 \mathrm{~g} \mathrm{~m}^{-2}$ & 180 & $\mathrm{~s}$ \\
\hline Aboveground production (reallocation not included) 2 & $375,16 \mathrm{~g} \mathrm{~m}^{-2}$ & $317,41 \mathrm{~g} \mathrm{~m}^{-2}$ & 180 & $\mathrm{~s}$ \\
\hline Belowground production 3 & $1561,92 \mathrm{~g} \mathrm{~m}^{-2}$ & $986,94 \mathrm{~g} \mathrm{~m}^{-2}$ & 180 & s \\
\hline Total production 4 & $1926,73 \mathrm{~g} \mathrm{~m}^{-2}$ & $1291,81 \mathrm{~g} \mathrm{~m}^{-2}$ & 180 & $\mathrm{~s}$ \\
\hline Solar radiation $\left(\mathrm{Kcal} \mathrm{m}^{-2}\right.$ day $\left.^{-1}\right)$ & $3826,33 \pm 1190,72$ & $3765,97 \pm 1449,90$ & 180 & ns \\
\hline Temperature $\left({ }^{\circ} \mathrm{C}\right)$ & $25,66 \pm 4,00$ & $22,88 \pm 2,92$ & 180 & $\mathrm{~s}$ \\
\hline Salinity $(\% o)$ & $11,54 \pm 6,34$ & $9,96 \pm 6,49$ & 180 & $\mathrm{~s}$ \\
\hline \multicolumn{5}{|c|}{$\begin{array}{l}\text { *Net primary production calculated by the model: } \\
\text { D Aboveground production (reallocation included) = gross production - aboveground respiration + reallocation - allocation (this } \\
\text { calculation is equivalent to the value obtained by the Smalley method, which takes in account gains and losses of biomass, not only by } \\
\text { production, but also by reallocation); } \\
\text { (2 Aboveground production (reallocation not included) = gross production - aboveground respiration - allocation (real net aboveground } \\
\text { production); } \\
3 \text { Belowground production = allocation - belowground respiration } \\
\mathbf{4} \text { Total production = gross production - aboveground respiration - belowground respiration }\end{array}$} \\
\hline
\end{tabular}

the values observed in the summer. Simulated live aboveground biomass exhibits values ranging along the year from $77.18 \mathrm{~g} \mathrm{~m}^{-2}$ to $365.36 \mathrm{~g} \mathrm{~m}^{-2}$ if reallocation is included. If reallocation is not included, these values decrease, ranging from $45.60 \mathrm{~g} \mathrm{~m}^{-2}$ to $232.03 \mathrm{~g} \mathrm{~m}^{-2}$, which represents a decrease of about $40 \%$. The reallocation occurs during the spring, and rapidly diminishes when the aboveground biomass is enough to produce and stock photosynthate.

Spartina can grow at salinities about 30 (Dame \& Kenny, 1986; Howes et al., 1986; Lana et al., 1991), but its best development occurs at salinity between 5 and 10 (Longstreth \& Strain, 1977; Linthurst \& Blum, 1981; Linthurst \& Seneca, 1981; Bradley \& Morris, 1992). The effects of salinity seem to be stronger for growth than for mortality (Linthurst \& Seneca, 1981; Howes et al., 1986; Bradley \& Morris, 1992). However, during the summer in the Patos Lagoon estuary, when salinity values were high, the also high solar radiation seemed to compensate the negative effect of salinity on Spartina production.

\section{Live and dead belowground biomass}

The simulated live belowground biomass showed a similar pattern to that of live aboveground biomass, with peak values higher in 1993 than in 1994 (Figure $3 \mathrm{C}$ ), but the observed belowground biomass presented high variability. Because of this variability, which is partially caused by spatial heterogeneity of rhizomes and roots, seasonal pattern of belowground components was not so clear as aboveground. Despite the large ran- ge of values each month, we could detect a peak of observed belowground biomass (May/1993) just after the peak of observed aboveground biomass, when photosynthate allocation from above to belowground biomass is usually high (Hull et al., 1976; Lytle \& Hull, 1980a,b,c; Hopkinson \& Schubauer, 1984).

Observed dead belowground biomass did not show a seasonal pattern, as suggested by the model output (Figure 3D), and observed biomass peaks occurred in the end of winter and early spring. The overestimation of dead belowground biomass by the model is probably a result of the difficulty to identify dead roots in the samples. If we could better identify dead roots and dead rhizomes, this compartment could be bigger than we detected.

\section{Standing dead biomass and litter}

The simulated standing dead biomass pattern showed a good agreement with the observed data in the first year, but the values were overestimated in the second year of the study (Figure 4A). It suggests that losses of standing dead biomass are not completely represented by the model, particularly in the late winter and spring.

Standing dead biomass has two kinds of losses in the model: decomposition and litter production (fall to the sediment surface). Standing dead Spartina decomposition and its interaction with temperature, rain, and air humidity, are represented in the model by empirical formulations, and it reproduces adequately the patterns observed by Newell et al. (1985). Estimates of 

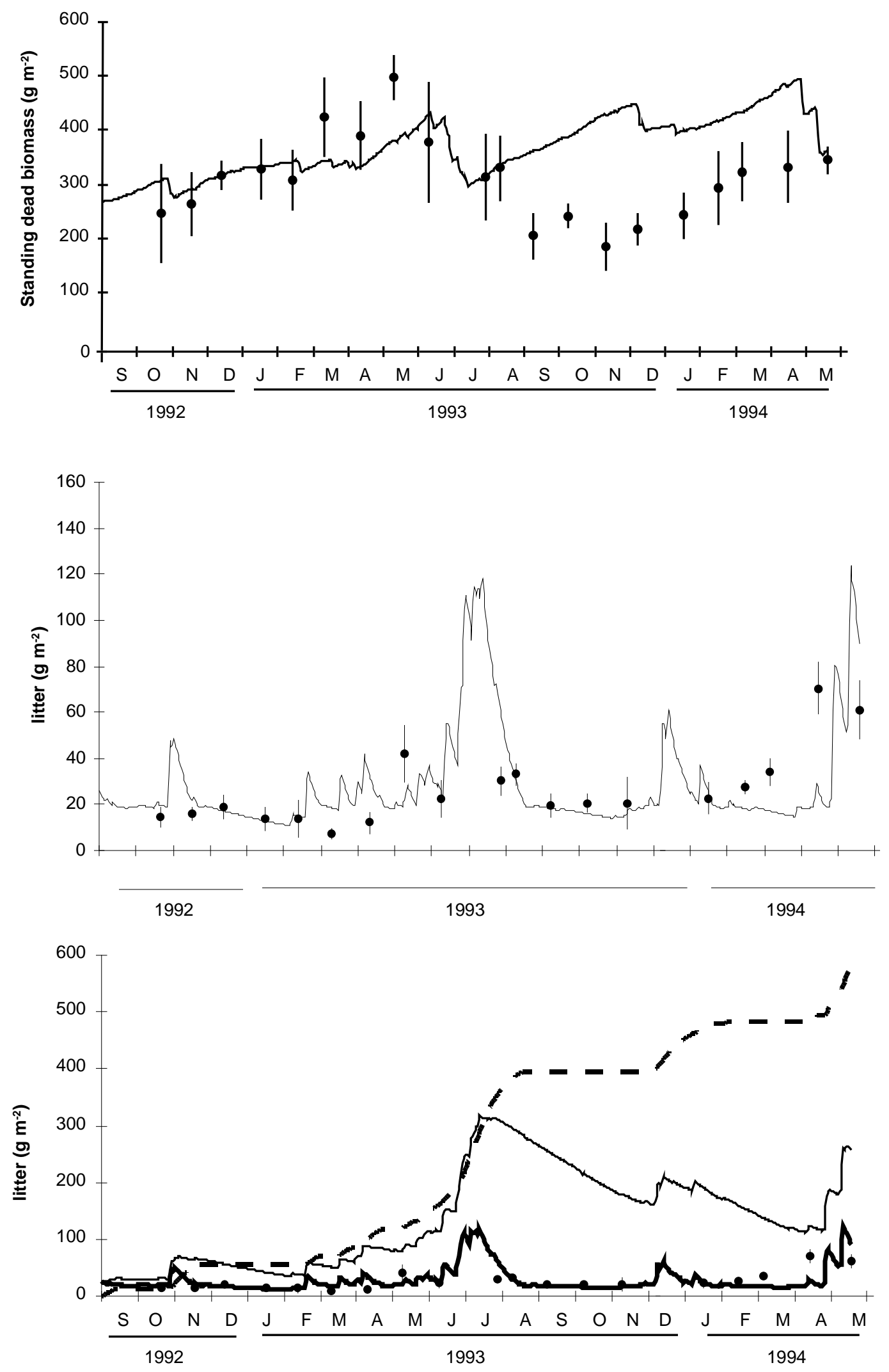

Figure 4 - Continuous lines are simulation output, points are mean observed values and vertical lines are one standard deviation. (A) Standing dead biomass; (B) Litter on substrate surface; (C) Simulated litter: (thick line) standard simulation, (thin line) simulation when the only lost of litter is decomposition, (dashed line) simulation of accumulation of litter removed by standard simulation. 
organic matter fluxes from standing dead biomass (Newell et al., 1989) indicate that about $30 \%$ of organic matter is lost as $\mathrm{CO}_{2}$ due microbial action, while the rest is lost as lixiviate or particulate organic matter. The model output was coherent with this data, presenting accumulated losses about $30 \%$ as a result of decomposition at the end of a 21-month simulation.

The accumulation of simulated standing dead biomass in the second season can be a consequence of not including grazing by residents and migratory organisms. It can also be influenced by the inefficient representation of physical influences on removal of standing dead biomass. The direct consumption of Spartina live aboveground biomass by grazers has been considered not significant in scientific literature, but some invertebrates are responsible by losses of standing dead Spartina by direct ingestion or even by fragmentation during feeding, as observed by Newell \& Bärlocher (1993). They found that the mollusk Littoraria irrorata, when in high densities (about 400 organisms/ $\mathrm{m}^{2}$ ), could consume 2 to $3 \%$ of standing dead Spartina and its epiphytic microbial community in one day. D'Incao et al. (1990) observed that the crab Chasmagnatus granulata, present in high densities in Patos Lagoon salt marshes, preferentially grazes on dead shoots, roots and rhizomes of Spartina. The authors also observed that vascular plants represented $34 \%$ of Chasmagnatus gut contents and were present in $80 \%$ of the observed crabs. Spartina seems to be the main alimentary item of the crab Metasesarma rubripes in Patos Lagoon salt marshes (Capitoli et al., 1977). Additional studies are needed on crabs' biomass estimates and on rates of crabs grazing on Spartina, and that data must be included in the model formulation.

The influence of physical factors on litter production is difficult to quantify. The influence of rain and water level variation was introduced in the model in an experimental way, as an attempt to get information about the role of these factors as controllers of litter production. This inclusion improved the model results, allowing the representation of some losses of standing dead Spartina. The importance of rain and water level variation on the disappearance of standing dead Spartina is shown in the Figure 4B, by comparing a simulation including litter production, and another simulation where the only loss of standing dead biomass is the decomposition process.

Even though the inclusion of litter production improved the model output for standing dead Spartina, the accumulation of simulated standing dead biomass since September 1993, indicates that litter production is not well enough represented in the model. The sharp decrease of the observed standing dead biomass occurred between august and September 1993 (Figure $4 \mathrm{~A})$ could be related to heavy rains in this period (31 $\mathrm{mm}$ between August 28 and August 31). On the other hand, similar rain values were observed in the same year without such an intense loss of standing dead biomass (e.g.: $29 \mathrm{~mm}$ between November 14 and November 17). These observations suggest the necessity of considering not only the rain quantity, but also the rain intensity during the period. If it rains 10 $\mathrm{mm}$ in 1 hour, much more standing dead Spartina will be broken, than if it rains $10 \mathrm{~mm}$ in 24 hours. The age of the standing dead biomass must be also considered, since an old dead plant (longer exposure to microbial and grazers actions) will be more easily broken with the rain than a recently dead plant. Therefore, it is necessary to perform further studies about these factors to represent, in a more adequate way, the losses of standing dead Spartina and litter production in the model.

Litter on the sediment surface has very low values when compared with standing dead biomass. If the model includes litter losses only by decomposition, it shows an accumulation of $320 \mathrm{~g} \mathrm{~m}^{-2}$ from September 1992 to July 1993 (Figure 4C). This accumulation was not observed in the field, where maximum observed values were about $70 \mathrm{~g} \mathrm{~m}^{-2}$. Therefore, it seems possible that litter, as well as standing dead biomass, is being consumed by migratory or resident organisms, or exported to adjacent waters, or both. To try understanding the litter losses, a constant factor was included, which exports/consumes litter, when litter values are higher than mean value of the first year of study $\left(20 \mathrm{~g} \mathrm{~m}^{-2}\right)$. When this factor was included, the model output showed good agreement with observed data (Figures 4C). The simulated exported/consumed litter resulted in a total of accumulated litter of $573.25 \mathrm{~g}$ $\mathrm{m}^{-2}$ at the end of 21 month of simulation (Figure 4C). This value evidences the potential contribution of salt marsh production to adjacent estuarine waters and for organisms.

The influences of physical factors on litter and standing dead Spartina losses are quite complex and have been analyzed in an integrated way. The attempts to quantify the contribution of this material to estuarine waters should take into account field experiments and the coupling of ecological to hydrological models for the salt marsh water column, which analyzes measurements of organic matter fluxes, tides, storms, rain, and runoff. In the Patos Lagoon estuary, water level, and consequently frequency and extension of salt marshes flooding, have seasonal variations, similar to the vegetation. A hydrological model for this environment should consider these physical and biological seasonality, since the water circulation and transport into salt marshes and tidal creeks depend on pressure gradients generated by tide and depends on vegetation density (Kjerfve et al., 1991). The particulate organic matter is not always carried out by tide, but accumulates 
into the salt marshes, until being carried out by runoff, especially during storms or heavy rains, as observed by Chalmers et al. (1985). These authors also observed that tidal turbulent fluxes could suspend particulate organic matter and sediments deposited into tidal creeks, and this material could be deposited into the salt marshes during ebb tide, due to low current velocities. This material could stay there until being carried out by runoff.

In Patos Lagoon salt marshes, rain seems to contribute effectively, by carrying out more standing dead Spartina and litter than we could represent in the model. Rain seems to be more important than tide on carrying out material, because tidal range is small in the estuary and salt marshes are irregularly flooded by tide, which is highly dependent on the amount of rain in the hydrographical basin.

\section{FINAL REMARKS}

The model reasonably simulates the main processes of Spartina alterniflora biomass in the estuary of Patos Lagoon, being particularly useful for the understanding of irregularly flooded marshes behavior, since most of the information on salt marsh ecology is related to regularly flooded ones. Certainly a more comprehensive model validation is still necessary in order to deeply explore the salt marsh behavior under different environmental conditions. Nevertheless the model can reasonable indicates the role of environmental factors of production, accumulation and losses of Spartina biomass, helping to explain the role of temperature, water runoff and water level as controllers of organic matter input to the estuary. Such controls can be fundamental for the dynamics of the salt marsh and for the ecology of the Patos Lagoon estuarine area.

\section{REFERENCES}

Adam, P. 1990. Saltmarsh Ecology. Cambridge University Press. New York, 461 pp.

Asmus, M.L. 1990. Ecological Modelling of the North Inlet Marsh-Estuarine System, South Carolina. Ph.D. Dissertation. University of South Carolina.

Benner, R.; Fogel, M.L. \& Sprague, E.K. 1991. Diagenesis of Belowground Biomass of Spartina alterniflora in Salt-marsh Sediments. Limonology and Oceanography, 36(7):1358-1374.

Blum, L.K. 1993. Spartina alterniflora Root Dynamic in a Virginia Marsh. Mar. Ecol. Progress Series,102:169-178.
Bradley, P.M. \& Morris, J.T. 1992. Effect of Salinity on the Critical Nitrogen Concentration of Spartina alterniflora Loisel. Aquatic Botany, 43:149-161.

Brock, T.D. 1981. Calculating Solar Radiation for Ecological Studies. Ecological Modelling, 14:1-19.

Capitoli, R.; Bemvenuti, C. E. \& Gianuca, N. M. 1977. Ocorrência e Observações Bio-ecológicas do Caranguejo Metasesarma rubripes (Rathbun) na Região Estuarial da Lagoa dos Patos. Atlântica, 2(1):50-62.

Chalmers, A.G.; Wiegert, R.G. \& Wolf, P.L. 1985. Carbon Balance in a Salt Marsh: Interactions of Diffusive Export, Tidal Deposition and Rainfall-caused Erosion. Estuarine, Coastal Shelf and Science, 21:757-771.

Childers, D. L. \& McKellar Jr, H. N. 1987. A simulation of Saltmarsh water colunm dynamics. Ecological Modelling, 36:211:238.

Cunha, S. R. 1994. Modelagem ecológica das marismas de Spartina alterniflora Loisel. (Poaceae) do estuário da Lagoa dos Patos, RS. Tese de Mestrado. Universidade do Rio Grande.

D'Incao, F.; Silva, K. G.; Ruffino, M. L. \& Braga, A. C. 1990. Hábito Alimentar do Caranguejo Chasmagnathus granulata Dana, 1851 na Barra do Rio Grande, RS (Decapoda, Grapsidae). Atlântica, 12(2):85-93.

Dame, R. F. \& Kenny, P. D. 1986. Variability of Spartina alterniflora Primary Production in the Euhaline North Inlet Estuary. Marine Ecology Progress Series, 32:71-80.

Day Jr., J. W.; Hall, C. A.; Kemp, W. M. \& YáñezArancibia, A. 1989. Estuarine Ecology. John Wiley \& Sons, New York, 558 pp.

Drake, B. G. 1989. Photosynthesis of Salt Marsh Species. Aquatic Botany, 34:167-1180.

Gallagher, J. L. 1983. Seasonal Patterns in Recoverable Underground Reserves in Spartina alterniflora Loisel. Ameican Journal of Botany, 70(2):212-215.

Giurgevich, J. R. \& Dunn, E. L. 1979. Seasonal Patterns of $\mathrm{CO}_{2}$ and Water Vapor Exchange of the Tall and Short Height Forms of Spartina alterniflora Loisel in a Georgia Salt Marsh. Oecologia, 43:139-156.

Gleason, M. L. \& Dunn, E. L. 1982. Effects of Hypoxia on Root and Shoot Respiration of Spartina alterniflora. In: V. S. Kennedy (ed.), Estuarine Comparisons, Academic Press, New York, 243-253 p.

Hopkinson, C. S. \& Schubauer, J. P. 1984. Static and Dynamic Aspects of Nitrogen Cycling in the Salt Marsh Graminoid Spartina alterniflora. Ecology, 65(3):961-969.

Howes, B. L.; Dacey, J. W. H. \& Goehringer, D. D. 1986. Factors Controlling the Growth Form of Spartina alterniflora: Feedbacks Between Aboveground 
Production, Sediment Oxidation, Nitrogen and Salinity. Journal of Ecology, 74:881-898.

Hull, R. J.; Sullivan, D. M. \& Lytle, R. W. 1976. Photosynthate Distribution in Natural Stands of Salt Water Cordgrass. Agronomy Journal, 68:969-972.

Jordan, T. E.; Pierce, F. W. \& Correll, D. L. 1986. Flux of Particulate Matter in the Tidal Marshes and Subtidal Shallows of Rhode River Estuary. Estuaries, 9(4b):310-319.

Jørgensen, S. E. 1994. Fundamentals of Ecological Modelling. 2nd Edition. Elsevier, Amsterdam, 629 $\mathrm{pp}$.

Kjerfve, B.; Miranda, L. B. \& Wolanski, E. 1991. Modelling Water Circulation in an Estuary and Intertidal Salt Marsh System. Netherlands Journal of Sea Research, 28(3):141.147.

Lana, P. C.; Guiss, C. \& Disaro, S. T. 1991. Seasonal Variation of Biomass and Production Dynamics for Above and Belowground Components of a Spartina alterniflora Marsh in the Euhaline Sector of Paranagua Bay (SE Brasil). Estuarine, Coastal and Shelf Science, 32:231-241.

Linthurst, R. A. \& Blum, U. 1981. Growth Modifications of Spartina alterniflora by the Interaction of $\mathrm{pH}$ and Salinity Under controlled Conditions. Journal of Experimental Marine Biology and Ecology., 55:207218.

Linthurst, R. A. \& Seneca, E. D. 1981. Aeration, Nitrogen and Salinity as Determinants of Spartina Alterniflora Loisel. Growth Response. Estuaries, 4(1):53-63.

Longstreth, D. J. \& Strain, B. R. 1977. Effects of Salinity and Illumination on Photosynthesis and Water Balance of Spartina alterniflora Loisel. Oecologia, 31:191-199.

Lytle, Jr, R. W. \& Hull, R. J. 1980a. Photoassimilate Distribution in Spartina alterniflora Loisel. I. Vegetative and Floral Development. Agronomy Journal, 72:933-938.

Lytle, Jr, R. W. \& Hull, R. J. 1980b. Photoassimilate Distribution in Spartina alterniflora Loisel. II. Autumn and Winter Storage and Spring Regrowth. Agronomy Journal, 72:938-942.

Lytle, Jr, R. W. \& Hull, R. J. 1980c. Annual Carbohydrate Variation in Culms and Rhizomes of Smooth Cordgrass (Spartina alterniflora). Agronomy Journal, 72:942-946.

Mann, K. 1988. Production and Use of Detritus in Various Freshwater, Estuarine end Coastal Marine Ecosystems. Limonology and Oceanography,33(4, part 2.):910:930.

Mitsch, W. J. \& Gosselink, J. G. 1986. Wetlands. Van Nostrand Reinhold Company, New York, 539 pp.

Morris, J. T. 1982. A Model of Growth Responses By Spartina alterniflora to Nitrogen Limitation. Journal of Ecology, 70:25-42.
Morris, J. T. 1989. Modelling Light Distribution within the Canopy of the Marsh Grass Spartina alterniflora as a Function of Canopy Biomass and Solar Angle. Agricultural and Forest Meteorology, 46:349-361.

Morris, J. T.; Houghton, R. A. \& Botkin, D. B. 1984. Theoretical Limits of Belowground Production by Spartina alterniflora: An Analysis Through Modelling. Ecological Modelling, 26:155-175.

Newell, S. Y.; Fallon, R. D.; Rodriguez, R. M. \& Groene, L. C. 1985. Influence of Rain, Tidal Wetting and Relative Humidity on Release of Carbon Dioxide by standing-Dead Salt Marsh Plants. Oecologia, 68:7379.

Newell, S. Y.; Fallon, R. D. \& Miller, J. D. 1989. Decomposition and Microbial Dynamics for Standing, Naturally Positioned Leaves of the SaltMarsh Grass Spartina alterniflora. Marine Biology, 101:471-481.

Newell, S. Y. \& Bärlocher, F. 1993. Removal of Fungal and Total Organic Matter from Decaying Cordgrass Leaves by Shredder Snails. Journal of Experimental Marine Biology and Ecology., 171:39-49.

Nobel, P. S. 1991. Physicochemical and Environmental Plant Physiology. Academic Press, California. 635 $\mathrm{pp}$.

Odum, H. T. 1983. Systems Ecology. WileyEnterscience. 644 pp.

Panitz, C. M. N. 1986. Produção e decomposição de serrapilheira no mangue do Rio Itacorubi, Ilha de Santa Catarina, Florianópolis, Brasil. Tese de Doutorado, Universidade de São Carlos, Brasil.

Summers, J. K. \& McKellar Jr, H. N. 1978. A Simulation Model of Estuarine Subsystem Coupling and Carbon Excange with the Sea. - I. Model Structure. In: S. E Jørgensen (ed.), State of the Art in Ecological Modelling. Int.Soc. Ecol. Modelling. Pergamon Press, Copenhagen, , 323-366p.

Wiegert, R. G.; Christian, R. R. \& Wetzel, R.L. 1981. A Model View of the Marsh, p.183-218. In: L. R. Pomeroy \& R. G. Wiegert (Eds.). The Ecology of a Salt Marsh. Springer-Verlag, New York.

Wiegert, R. G. 1980. Modelling Salt Marshes and Estuaries: Progress and Problems. In: P. Hamilton \& MacDonald, K. B. (eds), Estuarine and Wetland Processes. Plenum Press, New York.

Wolaver, T. G.; Hutchinson, S. \& Marozas, M. 1986. Dissolved and Particulate Organic Carbon in the North Inlet Estuary, South Carolina: What Controls their Concentrations? Estuaries, 9(1):31-38.

Submetido: Outubro/2004 Revisado: Março/2005 Aceito: Julho/2005 